\title{
On non-adjacent letter repetition and orthographic processing: Lexical decisions to nonwords created by repeating or inserting letters in words
}

\author{
Emilia Kerr ${ }^{1} \cdot$ Jonathan Mirault ${ }^{1} \cdot$ Jonathan Grainger ${ }^{1}$
}

Accepted: 21 October 2020 / Published online: 24 November 2020

(C) The Author(s) 2020

\begin{abstract}
Informal observation suggests that it is harder to notice the spelling mistake in "silencne" than "silencre." This concurs with current evidence that non-adjacent letter repetition in correctly spelled words makes these words harder to recognize. One possible explanation is provided by open-bigram coding. Words containing repeated letters are harder to recognize because they are represented by fewer bigrams than words without repeated letters. Building on this particular explanation for letter-repetition effects in words, we predicted that nonwords in a lexical decision task should also be sensitive to letter repetitions. In particular, we examined two types of nonwords generated from the same baseword: (1) nonwords created by repeating one of the letters in the baseword (e.g., silence => silencne); and (2) nonwords created by inserting a letter that is not present in the baseword (e.g., silencre). According to open-bigram coding, nonwords created by repeating a letter are more similar to their baseword than nonwords created by inserting a letter, and this should make it harder to reject letter repetition nonwords than letter insertion nonwords. We put these predictions to test in one on-line pilot study $(n=31)$, one laboratory experiment $(n=36)$, and one followup on-line experiment $(n=40)$ where we manipulated the distance between repetitions (one, two, three, or four letters). Participants found it harder to reject repetition nonwords than insertion nonwords, and this effect diminished with increasing distance.
\end{abstract}

Keywords Letter repetition effects $\cdot$ Orthographic processing $\cdot$ Word recognition $\cdot$ Reading

\section{Introduction}

Some readers might have already noticed that detecting the spelling mistake indicated by a red underline in MS Word is particularly difficult when that mistake is caused by the repetition of a letter that is already in the word (e.g., silencne, repetititon). Among different possible accounts of this

Emilia Kerr

emilia.mkr@gmail.com

1 Laboratoire de Psychologie Cognitive, CNRS, Aix-Marseille University, 3 place Victor Hugo, 13331 Marseille, France phenomenon, there is one model of orthographic processing, the open-bigram model (Grainger \& van Heuven, 2004; Whitney ${ }^{1}$, 2001), which predicts this perceived difficulty. The core mechanism of this model is the way that locationinvariant letter order is encoded - via an unordered set of ordered contiguous and non-contiguous letter pairs referred to as "open-bigrams" (e.g., word = od, wd, or, wo, wr, rd). According to this coding scheme, there is only one openbigram in the nonword "silencne" that is incompatible with the incorrectly written word "silence" - that is the bigram "cn." On the other hand, if the typographical error is caused by the insertion of a letter that is not already present in the

\footnotetext{
${ }^{1}$ We dedicate this work to the memory of Carol Whitney (1963-2019). We only got to know about Carol's untimely passing-away when we tried to contact her while working on this article. Carol was a pioneer in the field of what we now call "orthographic processing," and her early contribution with the SERIOL model (Whitney, 2001) was of utmost importance. Carol was a great mind and a beautiful person.
} 
targeted word (e.g., silencre), then the number of incompatible open-bigrams is greater (er, $\mathrm{nr}, \mathrm{cr}$, re), hence making it easier to detect the error (we apply the parameters of the Grainger \& van Heuven, 2004, model in these calculations, see also Appendix A). In the present study we examine whether this anecdotal evidence finds support in a more a more tightly controlled empirical investigation. First, we summarize the current evidence for an impact of letter repetition on reading behavior, before describing the present manipulation and the predictions of alternative models of letter-position coding concerning this manipulation.

Although letter-repetition effects have been investigated using various paradigms in the past (e.g., Bjork \& Murray, 1977; Gomez, Ratcliff, \& Perea, 2008; Kanwisher, 1991; Mozer, 1989), Schoonbaert and Grainger (2004) were among the first to investigate effects of within-word letter repetition in a reading paradigm (see Harris \& Morris, 2000, for a demonstration of between-word repetition effects referred to as "orthographic repetition blindness"). This was an important step forward in an attempt to reveal an impact of letter repetition on the processes involved in visual word recognition. Schoonbaert and Grainger's (2004) study produced mixed findings. On the one hand they did report that target words with repeated letters were harder to respond to in a lexical decision task than words with no letter repetitions. On the other hand, they found that masked primes formed by removing a repeated letter in a target word (e.g., balnce-BALANCE) were no more effective than primes formed by removing a non-repeated letter (e.g., balace BALANCE). Furthermore, in an unprimed lexical decision task, nonword targets formed by removing a repeated letter from a real word (e.g., BALNCE) were not any harder to respond to than nonwords formed by removing a non-repeated letter (e.g., BALACE). It is this ensemble of letter-repetition effects for word targets and null effects for nonword primes that motivated the parameters implemented in the Grainger and van Heuven (2004) model. By simply imposing a limit on the number of letters that can intervene between the constituent letters of an open-bigram, set to two in the Grainger and van Heuven model, then the model could account for the complete set of findings.

One primary inspiration for the present study is the more recent work of Trifonova and Adelman (2019), which importantly renewed interest in letter-repetition effects, and crucially brought attention to the difficulty that a number of prominent models of orthographic processing have in accounting for such effects. Trifonova and Adelman (2019) performed regression analyses on several mega-studies of lexical decision and word naming (Balota et al., 2007; Brysbaert et al., 2016; Ferrand et al., 2010; Keuleers et al., 2012). They found a small but significant inhibitory influence of repeated letters when the repetition did not involve adjacent letters. The effects were modulated by the distance separating the repeated letters, being strongest with one to three intervening letters. Here we simply aimed to provide a further test of one possible explanation of these letter-repetition effects, that is intrinsically tied to the core principles of open-bigram coding. After excluding the special case of adjacent letter repetitions, often referred to as "double letters" (e.g., Caramazza \& Miceli, 1990; Fischer-Baum, 2017), open-bigram coding offers a principled $^{2}$ account of non-adjacent letter-repetition effects, since letter repetition affects the number of open-bigrams that are generated by a written word, and open-bigram activation is the main mechanism governing activity in whole-word orthographic representations during silent reading (Grainger \& Ziegler, 2011; Snell, van Leipsig, Grainger, \& Meeter, 2018). ${ }^{3}$ Crucially, for the present work, in the Grainger and van Heuven (2004) model the number of incompatible openbigram representations plays a role via inhibitory connections between bigrams and whole words.

In the present study we apply what might arguably be the simplest of methodologies to reveal the effects of non-adjacent letter repetition on orthographic processing. We adopt a methodology that has already been successfully applied to investigate transposed-letter effects (Andrews, 1996; Bruner \& O’Dowd, 1958; Chambers, 1979; Frankish \& Turner, 2007; O'Connor \& Forster, 1981; Perea, Rosa, \& Gomez, 2005). The basic finding here is that nonwords created by transposing two letters in a real word (e.g., gadren - derived from "garden") are harder to classify as nonwords in a lexical decision task compared with nonwords formed by substituting two letters in a real word with different letters (e.g., gatsen). Building on the anecdotal evidence that it might be harder to detect typographical errors when these involve the erroneous repetition of a letter that is already part of the word, here we used performance to different types of nonword targets in a lexical decision task as a means to investigate this phenomenon in a controlled laboratory setting. We compared performance to two types of nonwords generated from the same baseword: (1) nonwords created by repeating one of the letters in the baseword (e.g., silencne); and (2) nonwords created by inserting a letter that is not present in the baseword (e.g., silencre). According to open-bigram theory, the "repeated letter" nonwords are more similar to their basewords than the "inserted letter" nonwords, and therefore should be harder to reject as a nonword in the

\footnotetext{
${ }^{2}$ The term "principled" is used here to underline the fact that open-bigram coding was not invented to account for letter-repetition effects or for transposed-letter effects (Grainger \& Whitney, 2004). These effects are true predictions derived from the core mechanism of this coding scheme. Core mechanisms are distinguished from parameters such as the maximum distance between two non-contiguous letters, and whether or not bigrams are weighted by distance or position (see Hannagan \& Grainger, 2012, for an analysis of such parameters within the more general framework of String kernels).

${ }^{3}$ Open-bigram coding is only one means to encode letter order information within a more general framework for visual word recognition that also allows for more precise order encoding (Grainger, 2018; Grainger \& Ziegler, 2011). The level of precision is determined by the nature of the task (silent reading vs. reading aloud) and the discriminability of the word with respect to all other words in the lexicon (more precision with low discriminability: Meade, Mahnich, Holcomb, \& Grainger, 2020).
} 
lexical decision task. Thus, for example, the repeated letter nonword "silencne" only contains a single open-bigram (cn) that does not occur in the baseword "silence." On the other hand, the nonword "silencre," formed by inserting a letter that is not in the baseword, contains multiple open-bigrams that do not occur in the baseword (see Davis, Perea, \& Acha, 2009, for prior evidence in favor of such inhibitory effects on the processing of nonwords in lexical decision). Therefore, it should be harder to reject "silencne" as a nonword compared with "silencre" because it is more similar to its baseword. We put these predictions ${ }^{4}$ to test in one laboratory experiment (Experiment 1) and one on-line experiment (Experiment 2) that provides a controlled investigation of the effects of distance between letter repetitions.

\section{Experiment 1}

\section{Methods}

Participants Thirty-six native speakers of French (29 female, mean age 21.8 years $(\mathrm{SD}=3.4)$ ) were recruited to complete the experiment in the laboratory setting. All reported having no neurological, language, or reading disorders. Participants were naive to the purpose of the experiment. Ethics approval was obtained from the Comite de Protection des Personnes SUD-EST IV (No. 17/051). A power analysis with the R package SIMR (Green \& MacLeod, 2016) performed on the data of an on-line pilot study testing the same stimuli as Experiment 1 (20 simulations) confirmed that the number of participants we recruited provided ample power for both response time ( $>80 \%$ power reached with $\mathrm{n}=19)$ and error rate models ( $>80 \%$ power reached with $\mathrm{n}=9$ ).

Design and stimuli 100 French words (see Appendix B) were selected from the Lexique database (version 3.83; New, Pallier, Brysbaert, \& Ferrand, 2004) that were between 8 and 12 letters in length (mean 8.68, SD 0.87) and did not contain accented letters. They were all relatively highfrequency singular nouns (mean $=4.20 \mathrm{Zipf}, \mathrm{SD}=0.47$ : van Heuven, Mandera, Keuleers, \& Brysbaert, 2014), and had an average OLD20 5 value of 2.64 (SD = 0.40: Yarkoni, Balota, $\&$ Yap, 2008). From these 100 basewords, two types of pronounceable and orthographically legal nonwords were created: (1) nonwords that contained a repeated letter from the baseword, e.g., adjudant - adjudtant; (2) nonwords that

\footnotetext{
${ }^{4}$ In Appendix A we provide predictions from different letter-position coding schemes. Note, nevertheless, that the experiments were entirely motivated by an open-bigram coding account of prior observations of letter-repetition effects in words.

${ }^{5}$ OLD20 measures the orthographic Levenshtein distance between a given letter sequence and all existing words. It takes the 20 closest (smallest) measures and outputs the average of those values.
}

contained a foreign letter inserted in the baseword, e.g., adjudant-adjudlant. For both types of nonwords, the repeated or inserted letter occupied the same position in the baseword, varied across all internal positions across the different basewords. The repeated/inserted letter was two to four positions away from the letter that was repeated (i.e., separated by one, two, or three intervening letters) and was never located in the initial or final position. Average letter frequency, calculated using lowercase token frequencies in French (New \& Grainger, 2011), was 9.49 Zipf (SD = 0.27) for the repeated letters and 9.38 $\mathrm{Zipf}(\mathrm{SD}=0.30)$ for the inserted letters. Letter frequency was included as a covariate in the statistical analyses. Since some basewords already contained repeated letters (47 out of 100, and mostly vowels), these letters were never involved in the repetition/insertion manipulation that always involved a consonant. Whether or not a baseword contained repeated letters was included as a covariate in the statistical analyses. The main factor was "type of nonword" - repetition versus insertion, and this was counterbalanced across participants using a Latin-square design. That is, two lists were created so that every participant was presented with a nonword derived from a given baseword in only one of the two conditions. OLD20 was used to control for differences in orthographic similarity to real words across the two sets of nonwords (mean $=3.25, \mathrm{SD}=0.41$ in the repetition condition; mean $=3.27, \mathrm{SD}=0.42$ in the insertion condition). These values were added as a covariate in the statistical analyses. Additionally, another 100 French words were selected from the Lexique database (with the same constraints as the basewords) for the purposes of the lexical decision task. The responses to these words were not analyzed.

Procedure Participants were engaged in a lexical decision task where they were asked to indicate as accurately and as rapidly as possible whether the stimulus presented on the screen was a real word or not. Prior to the experiment, all participants signed a written consent form. Participants were comfortably seated in a testing room in front of a computer screen at a distance of approximately $70 \mathrm{~cm}$. Stimuli were presented in lowercase letters on a computer monitor controlled by OpenSesame (version 3.1.9, Mathôt, Schreij, \& Theeuwes, 2012). Each trial began with a fixation cross presented in the center of the screen for a random duration from 250 to $350 \mathrm{~ms}$ followed by the target word (a nonword or a real word) that stayed on the screen until the response was made. After each trial a feedback dot was provided in green (correct) or red (incorrect) presented for $300 \mathrm{~ms}$. The intertrial interval was $200 \mathrm{~ms}$. Prior to the main experiment, ten practice trials were completed by participants in order to familiarize them with the procedure. In the main experiment each participant completed 200 trials -100 nonwords and 100 real words. Trial presentation was randomized with a different random order per participant. The experiment lasted approximately $10 \mathrm{~min}$. 


\section{Results}

We computed response accuracy and response time (RT: the duration between the onset of the presentation of the target and the keyboard response) for correct responses. Participants performed with an average accuracy of $86.1 \%(\mathrm{SD}=34.5)$. We used Linear Mixed Effects Model (LME) to analyze RTs and Generalized (logistic) Linear Mixed Effects Model (GLME) to analyze response accuracy, with participants and items as crossed random effects (Baayen, Davidson, \& Bates, 2008; Barr, Levy, Scheepers, \& Tily, 2013). The models were fitted with lmer (for LME) and the glmer (for GLME) functions from the lme4 package (Bates, Maechler, Bolker, \& Walker, 2015) in the R statistical computing environment (version 3.3.1, R Core Team, 2017). We report regression coefficients (b), standard errors (SE), and $t$-values (for LMEs) or $z$-values (for GLMEs). Fixed effects were deemed reliable if $|t|$ or $|z|>$ 1.96 (Baayen, 2008). We used the control condition as the reference. RTs were inverse-transformed $(-1,000 / \mathrm{RT})$ prior to analysis. We used the maximal random structure model that converged (Barr et al., 2013), and this included by-participant and by-item random intercepts in all analyses that we report.

\section{Response times}

Prior to the analysis, we excluded incorrect responses $(10.1 \%)$, leaving a dataset of 2,977 observations. RTs beyond $2.5 \mathrm{SD}$ from the grand mean were removed before analysis (2.78\%), leaving a total of 2,894 data points. RTs were significantly slower $(b=0.06, \mathrm{SE}=0.029, t=2.2)$ to nonwords with a repeated letter $(\mathrm{M}=875 \mathrm{~ms}, 95 \% \mathrm{CI}=31)$ compared to nonwords with a foreign inserted letter $(\mathrm{M}=841 \mathrm{~ms}, 95 \% \mathrm{CI}$ $=30)$.

\section{Error rates}

Based on 3,312 observations we observed a significant effect of Type of Nonword $(b=1.2, \mathrm{SE}=0.31, z=3.8)$, with error rates being significantly higher in the repetition condition (M $=14.5 \%, 95 \% \mathrm{CI}=2.9$ ) compared to the insertion condition $(\mathrm{M}=5.7 \%, 95 \% \mathrm{CI}=3.2)$.

\section{Discussion}

Experiment 1 provided clear support for our hypothesis that nonwords created by repeating a letter that is already present in a given baseword word (e.g., silencne from the baseword silence) are harder to reject compared with nonwords created by inserting a letter that is not present in the baseword (e.g., silencre). The repeated letters were separated by at least one letter (i.e., no adjacent repetitions) and fewer than four letters. In order to provide a preliminary analysis of the effects of distance, we performed post hoc analyses including distance as a factor. There were seven items for distance 1, 50 items for distance 2 , and 43 items for distance 3 . The repetition effect was $52 \mathrm{~ms}$ in RTs and $10.5 \%$ in errors for distance $1,56 \mathrm{~ms}$ in RTs and $12.4 \%$ in errors for distance 2 , and $6 \mathrm{~ms}$ and $4.1 \%$ for distance 3 . The interaction between repetition and distance was significant for errors $(b=-$ $0.6, \mathrm{SE}=0.22, z=2.78$ ). On the basis of these preliminary findings we decided to run an experiment manipulating distance.

\section{Experiment 2}

\section{Methods}

Participants Forty native speakers of French (15 males, mean age 27.5 years $(\mathrm{SD}=11.6)$ ) were recruited to complete the experiment online. All reported having no neurological, language, or reading disorders. Participants were naïve to the purpose of the experiment.

Design and stimuli 200 French words (see Appendix C) were selected from the Lexique database (version 3.83; New, Pallier, Brysbaert, \& Ferrand, 2004) that were eight letters in length and did not contain accented letters. They were all relatively high-frequency words (mean 4.25 Zipf, SD = 0.41 ), and had an average OLD20 value of 2.28 (SD = 0.39). From these 200 basewords, two types of pronounceable and orthographically legal nonwords were created as in Experiment 1. The main factors were (1) Type of Nonword - repetition vs. insertion, and (2) Distance (i.e., the repeated/ inserted letter was separated by one, two, three, or four intervening letters, 50 nonwords per distance and type of nonword). This was counterbalanced across participants using a Latin-square design. The average frequency of the repeated letters was 9.43 $\mathrm{Zipf}(\mathrm{SD}=0.34)$ and $9.43 \mathrm{Zipf}(\mathrm{SD}=0.30)$ for the inserted letters. Additionally, another 200 French words of nine letters in length were selected from the Lexique database for the purposes of the lexical decision task. The responses to these words were not analyzed.

Procedure Participants were engaged in a lexical decision task as in Experiment 1. The stimulus presentation was controlled using an in-house script.

\section{Results}

The analysis methods performed in Experiment 2 were the same as in Experiment 1. Participants performed with an average accuracy of $92.5 \%(\mathrm{SD}=26.3)$. Mean RTs and error rates with differences between the conditions (repetition effects) are presented in Table 1. 
Table 1 Mean response times (RTs, ms) and percent errors (\%ER) per condition in Experiment 2, and repetition effects (difference between the repetition and insertion conditions) per distance

\begin{tabular}{|c|c|c|c|c|c|c|c|c|}
\hline & \multicolumn{2}{|c|}{ Distance 1} & \multicolumn{2}{|c|}{ Distance 2} & \multicolumn{2}{|c|}{ Distance 3} & \multicolumn{2}{|c|}{ Distance 4} \\
\hline & RT & $\% \mathrm{ER}$ & RT & $\%$ ER & RT & $\%$ ER & RT & $\%$ ER \\
\hline Repetition & 845 (39) & $10.0(3.9)$ & 839 (38) & $13.2(3.8)$ & 825 (37) & $12.5(3.8)$ & 817 (36) & $8.8(3.9)$ \\
\hline Insertion & 758 (35) & $2.1(4.0)$ & $792(36)$ & $3.0(4.0)$ & 803 (36) & $5.0(4.0)$ & 780 (34) & $5.0(4.0)$ \\
\hline Difference & 87 & 7.9 & 47 & 10.2 & 22 & 7.5 & 37 & 3.8 \\
\hline
\end{tabular}

Note. $95 \%$ CIs are shown in parentheses

\section{Response times}

Prior to the analysis, we excluded incorrect responses (7.5\%), leaving a dataset of 7,401 observations. RTs beyond and below $2.5 \mathrm{SD}$ from the grand mean were removed before analysis $(0.96 \%)$, leaving a total of 7,330 data points. RTs were found to be significantly slower $(b=0.12, \mathrm{SE}=0.02, t=6.8$ ) to nonwords with a repeated letter $(\mathrm{M}=834 \mathrm{~ms}, 95 \% \mathrm{CI}=$ 19.1) compared to nonwords with a foreign inserted letter (M $=785 \mathrm{~ms}, 95 \% \mathrm{CI}=17.9)$. Crucially, the Type of Nonword $\times$ Distance interaction was significant $(b=0.02, \mathrm{SE}=0.007, t=$ 3.12). Repetition effects were significant for distances 1,2 and $4(b=0.01, \mathrm{SE}=0.02, t=7.75 ; b=0.07, \mathrm{SE}=0.01, t=4.92 ; b$ $=0.07, \mathrm{SE}=0.01, t=5.08)$, but not for distance $3(b=0.02$, $\mathrm{SE}=0.017, t=1.36$ ).

\section{Error rates}

Based on 8,000 observations, we observed a significant effect of the Repetition factor $(b=2.1, \mathrm{SE}=0.263, z=8.01)$, with error rates being significantly higher in the repetition condition ( $\mathrm{M}=11 \%, 95 \% \mathrm{CI}=2)$ compared to the insertion condition $(\mathrm{M}=3.85 \%, 95 \% \mathrm{CI}=3)$. The Type of Nonword $\times$ Distance interaction was significant $(b=0.34, \mathrm{SE}=0.009, z$ = 3.9). Overall, the effects of repetition diminished with increasing distance, but were significant for all four distances $(b$ $=1.9, \mathrm{SE}=0.3, z=6.9 ; b=1.6, \mathrm{SE}=0.20, z=8.06 ; b=1.1$, $\mathrm{SE}=0.18, z=6.07 ; b=0.6, \mathrm{SE}=0.18, z=3.4)$.

\section{Inverse efficiency}

Given the theoretical importance of the distance factor (see Appendix A) and given the conflicting pattern in RTs and error rates (see Table 1, where opposite effects of repetition can be seen in RTs and errors across distances 1 and 2, and 3 and 4), we decided to compute inverse efficiency scores (IES) that combine RTs and error rates per condition and per participant. Inverse efficiency is obtained by dividing mean RT by probability correct (e.g., a mean RT of $500 \mathrm{~ms}$ with $90 \%$ accuracy gives $500 / 0.9=556)$. The condition means are shown in Fig. 1. A by-participant ANOVA was performed on these data with Type of Nonword (repetition vs. insertion) as a factor and Distance (1-4) as a covariate. The main effect of Type of Nonword was significant $(\mathrm{F}(1,158)=74.53, p<$ $.001)$, as was the interaction between Type of Nonword and Distance $(\mathrm{F}(1,158)=15.18, p<.001)$. As can be seen in Fig. 1 , the effects of Type of Nonword diminished with increasing Distance.

\section{Discussion}

The results of Experiment 2 perfectly replicate the letterrepetition effect reported in Experiment 1 and enable a more precise evaluation of the impact of the distance (in number of letters) separating the repeated letters. This impact is best seen in Fig. 1, which reports a combined measure of RTs and error rates in the form of inverse efficiency. Here it is clear that the effects of non-adjacent letter repetition gradually diminish as the distance between the repeated letters increases. We examine the theoretical importance of these findings below.

\section{General discussion}

In the present study we compared performance of two types of nonwords in a lexical decision task. These two types of nonwords were generated from the same set of basewords (e.g., silence) by either repeating a letter that is already present in the word (e.g., silencne) or by inserting a letter that is not present in the word (e.g., silencre), with the repeated letters separated by at least one letter and fewer than four letters in Experiment 1, and one to four letters in Experiment 2. In both experiments we observed that the repetition nonwords were harder to classify as such than the insertion nonwords, in terms of both RTs and error rates. This is a novel finding that we expect will provide important additional constraints on models of letter position coding and orthographic processing.

The letter-repetition effect on nonword processing was predicted by Grainger and van Heuven's (2004) model of orthographic processing. The core mechanism of this model is the way in which location-invariant letter order information is encoded via a bag of contiguous and non-contiguous ordered 


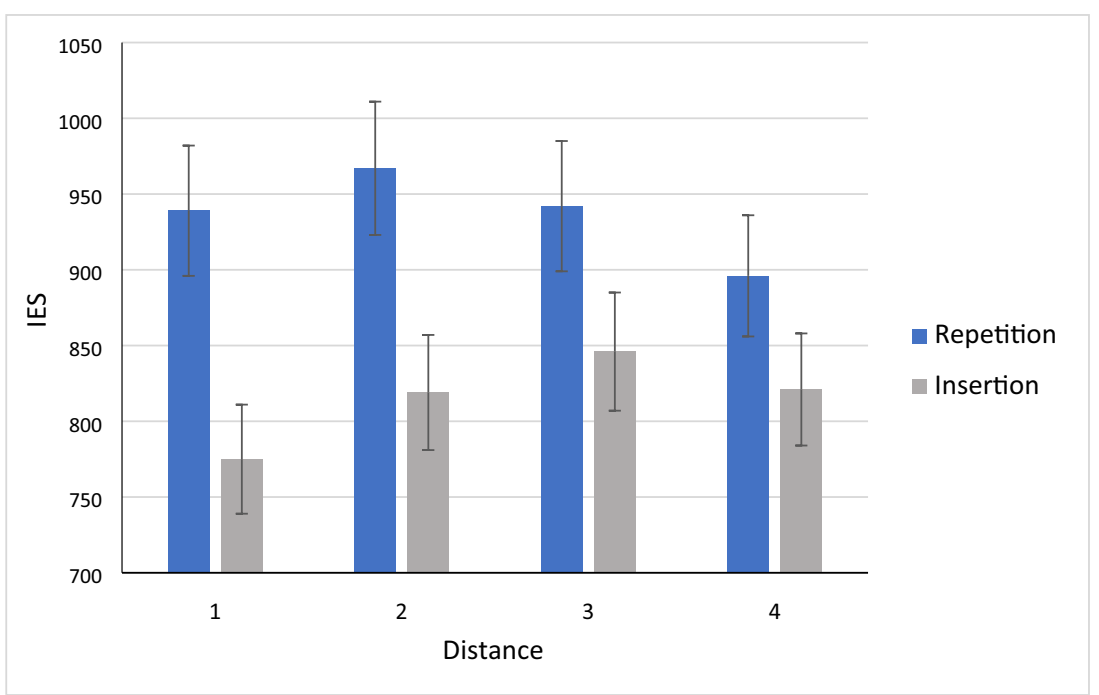

Fig. 1 Average inverse efficiency scores (IES: response time/probability correct) per condition in Experiment 2. Note that different basewords were used to create the nonwords tested in the different distance

pairs of letters (open-bigrams: Grainger \& Whitney, 2004; Whitney, 2001). Thus, in the version described by Grainger and van Heuven (2004), a word such as "silence" is represented by the unordered set of the following open-bigrams: si, sl, se, il, ie, in, le, ln, lc, en, ec, ee, nc, ne, ce. This model provided a straightforward account of the findings of Schoonbaert and Grainger (2004) and Trifonova and Adelman (2019) that words with non-adjacent repeated letters are harder to respond to in the lexical decision task than words that do not contain letter repetitions. Words with letter repetitions activate fewer open-bigrams, hence reducing the feedforward excitatory activity from bigrams to words. The fact that the Grainger and van Heuven (2004) model also implements inhibitory connectivity between bigrams and words led us to predict the pattern of results seen with nonword stimuli in the present study. Insertion nonwords contain more open-bigrams that are incompatible with the baseword than do repetition nonwords. Incompatible bigrams inhibit whole-word representations, such that the more incompatible bigrams there are in a target nonword the more the corresponding baseword will be inhibited, and the less likely this word will be perceived instead of the nonword. This therefore accounts for the observed greater ease in classifying insertion nonwords as such compared with the repetition nonwords.

As can be seen in Appendix A, the overlap model of Gomez et al. (2008) accurately accounts for the present findings. The parameters implemented in the simulations described by Pablo Gomez (Gomez, 2020) enabled repeated letters to overlap in the repetition nonwords, hence increasing the evidence that only one of these letters is present, and therefore increasing similarity with the baseword. Furthermore, the same mechanism can also account for the inhibitory effects of letter repetition found with word stimuli conditions, so only the comparison between the repetition and insertion conditions per distance is relevant here. Differences in IES per distance are $164,148,96,75$. Error bars are $95 \%$ CIs

(Schoonbaert \& Grainger, 2004; Trifonova \& Adelman, 2019). Crucially, the overlap model also captures the monotonic decrease in repetition effects with distance seen in inverse efficiency scores in Experiment 2. On the other hand, the pattern of effects found in Experiment 2 is incompatible with Grainger and van Heuven's version of open-bigram coding (see Appendix A). However, Grainger and van Heuven (2004) did suggest that imposing a strict limit on the maximal distance for open-bigram representations was clearly an oversimplification, and a scheme where bigrams are weighted by distance would be a more viable solution. The results of Experiment 2 are in line with this conjecture. Such a version of open-bigram coding had already been proposed by Whitney (2001), and further support for this approach was provided by Hannagan and Grainger (2012).

Finally, we acknowledge that it is possible that the letterrepetition effects found with words (Schoonbaert \& Grainger, 2004; Trifonova \& Adelman, 2019) and with nonwords (the present study) might not reflect mechanisms involved in orthographic processing, but might be driven by some form of spatial repetition blindness (RB: e.g., Kanwisher, 1991; Luo \& Caramazza, 1996). If the second occurrence of a repeated letter was suppressed in some way, then this would make it harder to identify words with letter repetitions, and it would make the repeated letter nonwords look like their baseword. Here, it is important to note that Kanwisher (1991) investigated spatial RB with different kinds of stimuli - letters, symbols, and color patches - and found the effects to be quite similar for the different types of stimuli, hence pointing to a relatively low-level perceptual locus of the phenomenon. Furthermore, $\mathrm{RB}$ effects (both sequential and spatial) require quite short stimulus exposures (e.g., Kanwisher, 1991; Mozer, 1989), and spatial (simultaneous) RB is less pronounced than 
sequential RB (Kanwisher, 1991; Luo \& Caramazza, 1996). This evidence points to a limitation in the ability to sequentially allocate attention to the different items as the main source of RB. This is therefore a very different mechanism compared with the kind of parallel orthographic processing typically assumed to operate during visual word recognition (e.g., Adelman, Marquis, \& Sabatos-DeVito, 2010; Grainger, 2018)

In order to confirm the orthographic locus of letterrepetition effects, future research could compare repetition effects with different kinds of stimuli. This is possible using the same-different matching task, or the match-to-sample task used by (Gomez et al., 2008). In their Experiment 4, Gomez et al. (2008) found that accuracy dropped significantly when the target contained a letter repetition. It will be important to know whether such repetition effects in a relatively low-level task are of comparable magnitude for stimuli such as digits and symbols. The open-bigram account of letter-repetition effects predicts that the effects should be greater for letter stimuli, in the same manner as transposition effects in samedifferent matching (Duñabetia, Dimitropoulou, Grainger, Hernández, \& Carreiras, 2012; Massol, Duñabetia, Carreiras, \& Grainger, 2013; see Grainger \& Hannagan, 2014, for a review). On the other hand, the overlap model, which implements a generic order-encoding mechanism, predicts that similar repetition effects should be observed for different types of stimuli. This offers an interesting avenue for future research aiming at testing these different accounts of non-adjacent letter-repetition effects.

Acknowledgements This work was supported by ERC grant 742141 . The authors are deeply indebted to Julie Pynte for her assistance in running participants, to Pablo Gomez for the overlap model match calculations, and to Colin Davis for assistance with his Match Calculator.

Open Practices Statement The data and analysis scripts for the experiments are available at https:/osf.io/y82s7/ and Experiment 1 was preregistered at https://osf.io/c2xyh. Stimuli are provided in Appendices B and $\mathrm{C}$.

\section{Appendix A}

Predictions of three-letter-position coding schemes tested with the stimuli of Experiments 1 and 2 using Colin Davis' Match Calculator http://www.pc.rhul.ac.uk/staff/c.davis/utilities/matchcalc/index.htm for the SOLAR (spatial coding) model (Davis, 2010) and the binary Open Bigram model (Grainger \& van Heuven, 2004), and the values provided by Pablo Gomez for the Overlap model (Gomez, 2020). Significant $t$ values are in bold, and negative values indicate differences in the incorrect direction.

\begin{tabular}{|c|c|c|c|c|c|}
\hline \multicolumn{6}{|l|}{ Experiment 1} \\
\hline \multirow[t]{2}{*}{ Model } & & Mean (SD) & & t-test & \\
\hline & & Repetition & Insertion & Difference & $t$ \\
\hline \multicolumn{2}{|l|}{ SOLAR } & $0.914(0.03)$ & $0.922(0.03)$ & -0.008 & -4.23 \\
\hline \multicolumn{2}{|l|}{ Open Bigram } & $0.908(0.05)$ & $0.879(0.05)$ & 0.029 & 9.45 \\
\hline \multicolumn{2}{|l|}{ Overlap } & $3.052(0.27)$ & $3.000(0.27)$ & 0.052 & 10.75 \\
\hline \multicolumn{6}{|l|}{ Experiment 2} \\
\hline \multirow[t]{2}{*}{ Model } & Distance & Mean (SD) & & & t-test \\
\hline & & Repetition & Insertion & Difference & $t$ \\
\hline \multirow[t]{4}{*}{ SOLAR } & 1 & $0.900(0.02)$ & $0.900(0.02)$ & 0 & 0 \\
\hline & 2 & $0.902(0.01)$ & $0.907(0.02)$ & -0.005 & -2.25 \\
\hline & 3 & $0.935(0.02)$ & $0.935(0.01)$ & 0 & 0 \\
\hline & 4 & $0.956(0.02)$ & $0.956(0.01)$ & 0 & 0 \\
\hline \multirow[t]{4}{*}{ Opea Bigram } & 1 & $0.905(0.03)$ & $0.848(0.04)$ & 0.057 & 15.12 \\
\hline & 2 & $0.902(0.03)$ & $0.849(0.04)$ & 0.053 & 18.96 \\
\hline & 3 & $0.865(0.03)$ & $0.865(0.03)$ & 0 & 0 \\
\hline & 4 & $0.917(0.03)$ & $0.917(0.03)$ & 0 & 0 \\
\hline \multirow[t]{4}{*}{ Overlap } & 1 & $3.092(0.08)$ & $2.939(0.08)$ & 0.153 & 141.2 \\
\hline & 2 & $2.990(0.07)$ & $2.928(0.07)$ & 0.062 & 21.20 \\
\hline & 3 & $2.912(0.07)$ & $2.898(0.07)$ & 0.014 & 13.39 \\
\hline & 4 & $2.892(0.12)$ & $2.890(0.12)$ & 0.002 & 8.498 \\
\hline
\end{tabular}




\section{Appendix B}

Nonword stimuli tested in Experiment 1, and the basewords from which they were generated.

\begin{tabular}{|c|c|c|}
\hline Baseword & Repetition & Insertion \\
\hline adjudant & adjudtant & adjudlant \\
\hline adolescence & adsolescence & admolescence \\
\hline adversaire & adversairse & adversairle \\
\hline ambition & ambintion & ambiction \\
\hline amertume & amertumte & amertumse \\
\hline baignoire & baignoirne & baignoirge \\
\hline banlieue & banlienue & banlietue \\
\hline blancheur & blanchreur & blanchteur \\
\hline boulevard & bouledvard & bouletvard \\
\hline boutique & boubtique & boultique \\
\hline camarade & camadrade & camatrade \\
\hline campagne & campcagne & campragne \\
\hline caoutchouc & catoutchouc & camoutchouc \\
\hline capitaine & capitnaine & capitgaine \\
\hline catastrophe & catrastrophe & catlastrophe \\
\hline cauchemar & cauchermar & cauchetmar \\
\hline cercueil & cerclueil & cercnueil \\
\hline certitude & certitrude & certitsude \\
\hline chevalier & chevaliver & chevaliger \\
\hline chevelure & cheverlure & chevetlure \\
\hline circonstance & circornstance & circognstance \\
\hline compagnie & compnagnie & compragnie \\
\hline compagnon & comnpagnon & comspagnon \\
\hline comptoir & comptroir & comptloir \\
\hline concierge & concinerge & conciberge \\
\hline conclusion & consclusion & contclusion \\
\hline condition & contdition & consdition \\
\hline confiance & conficance & confirance \\
\hline confusion & confunsion & confugsion \\
\hline conscience & conscinence & conscidence \\
\hline conviction & contviction & condviction \\
\hline couvercle & couvlercle & couvdercle \\
\hline couverture & coutverture & coulverture \\
\hline discipline & discilpline & discimpline \\
\hline domicile & domilcile & domircile \\
\hline empereur & ermpereur & elmpereur \\
\hline escalier & escarlier & escaplier \\
\hline exercice & exercirce & exercince \\
\hline existence & existnence & existpence \\
\hline fauteuil & fautfeuil & fautreuil \\
\hline fermeture & fertmeture & ferbmeture \\
\hline fonction & foncticon & fonctibon \\
\hline fontaine & fontaitne & fontaigne \\
\hline gendarme & gendmarme & gendsarme \\
\hline grandeur & grandreur & grandleur \\
\hline habitude & habitbude & habitrude \\
\hline
\end{tabular}


(continued)

\begin{tabular}{|c|c|c|}
\hline harmonie & harmonrie & harmondie \\
\hline histoire & histroire & histloire \\
\hline ignorance & ignorgance & ignormance \\
\hline individu & indinvidu & indirvidu \\
\hline indulgence & indgulgence & indmulgence \\
\hline instinct & instninct & instrinct \\
\hline instrument & instrumtent & instrumpent \\
\hline jalousie & jalsousie & jalrousie \\
\hline journaliste & journasliste & journacliste \\
\hline lendemain & lendemdain & lendempain \\
\hline lieutenant & lienutenant & lierutenant \\
\hline longueur & longuenur & longuepur \\
\hline mensonge & mensgonge & menslonge \\
\hline ministre & mitnistre & midnistre \\
\hline monsieur & monsrieur & monstieur \\
\hline montagne & mogntagne & morntagne \\
\hline mouchoir & mohuchoir & moluchoir \\
\hline moustache & moucstache & mounstache \\
\hline nostalgie & nostnalgie & nostralgie \\
\hline ouverture & outverture & oumverture \\
\hline patience & pantience & paftience \\
\hline peinture & petinture & peminture \\
\hline perfection & pertfection & permfection \\
\hline poitrine & proitrine & ploitrine \\
\hline prestige & prestrige & prestnige \\
\hline principe & prinpcipe & prindcipe \\
\hline profondeur & pronfondeur & protfondeur \\
\hline promenade & promednade & promelnade \\
\hline province & pronvince & prodvince \\
\hline prudence & prundence & prusdence \\
\hline quartier & quartrier & quartlier \\
\hline question & questison & questihon \\
\hline religion & regligion & remligion \\
\hline retraite & retratite & retralite \\
\hline revolver & relvolver & remvolver \\
\hline sacrifice & scacrifice & slacrifice \\
\hline scandale & scandcale & scandrale \\
\hline sensation & sentsation & senbsation \\
\hline signature & snignature & spignature \\
\hline solution & solustion & soluction \\
\hline spectacle & spectlacle & spectracle \\
\hline sympathie & spympathie & slympathie \\
\hline tabouret & tarbouret & tambouret \\
\hline tendance & tendtance & tendjance \\
\hline tentative & tentantive & tentartive \\
\hline trahison & trahrison & trahmison \\
\hline tribunal & triburnal & tribudnal \\
\hline troupeau & trotupeau & trofupeau \\
\hline vendredi & verndredi & vemndredi \\
\hline vengeance & vengveance & vengdeance \\
\hline victoire & victroire & victmoire \\
\hline vingtaine & vingtnaine & vingtraine \\
\hline violence & violvence & violdence \\
\hline vocation & vocantion & vocastion \\
\hline
\end{tabular}




\section{Appendix C}

Nonword stimuli tested in Experiment 2 and the basewords from which they were generated.

\begin{tabular}{|c|c|c|c|}
\hline Baseword & Repetition & Insertion & Distance \\
\hline abstenir & abstsenir & abstmenir & 1 \\
\hline aiguiser & aigusiser & aiguliser & 1 \\
\hline ambition & ambibtion & ambirtion & 1 \\
\hline artifice & artrifice & artnifice & 1 \\
\hline aviateur & avivateur & avicateur & 1 \\
\hline banquier & banqnuier & banqluier & 1 \\
\hline blanchir & blanhchir & blanpchir & 1 \\
\hline calvaire & calvlaire & calvpaire & 1 \\
\hline carabine & cararbine & caratbine & 1 \\
\hline cercueil & cercrueil & cercnueil & 1 \\
\hline chanteur & chahnteur & chamnteur & 1 \\
\hline cheminer & chehminer & chetminer & 1 \\
\hline conjugal & conjnugal & conjrugal & 1 \\
\hline descente & descnente & descrente & 1 \\
\hline diminuer & dimimnuer & dimisnuer & 1 \\
\hline division & divivsion & divirsion & 1 \\
\hline douzaine & douzanine & douzabine & 1 \\
\hline escadron & escardron & escapdron & 1 \\
\hline estomper & estotmper & estohmper & 1 \\
\hline exclusif & exclsusif & excltusif & 1 \\
\hline expulser & expuplser & exputlser & 1 \\
\hline farouche & faroruche & faroduche & 1 \\
\hline faubourg & fauborurg & faubonurg & 1 \\
\hline flambeau & flalmbeau & flarmbeau & 1 \\
\hline fragment & frargment & fralgment & 1 \\
\hline gracieux & grarcieux & gratcieux & 1 \\
\hline hargneux & hargrneux & harglneux & 1 \\
\hline imaginer & imamginer & imacginer & 1 \\
\hline infliger & inflgiger & inflpiger & 1 \\
\hline invoquer & invovquer & invotquer & 1 \\
\hline lamenter & lamemnter & lamesnter & 1 \\
\hline lumineux & lumimneux & lumitneux & 1 \\
\hline migraine & migranine & migradine & 1 \\
\hline ministre & mininstre & minilstre & 1 \\
\hline novembre & novevmbre & novetmbre & 1 \\
\hline paisible & paisilble & paisirble & 1 \\
\hline patauger & patatuger & patanuger & 1 \\
\hline plaindre & plalindre & plabindre & 1 \\
\hline poitrine & poitrnine & poitrzine & 1 \\
\hline prestige & prerstige & prebstige & 1 \\
\hline purement & purerment & puresment & 1 \\
\hline relation & relaltion & relaption & 1 \\
\hline rudement & rudedment & redelment & 1 \\
\hline scandale & scandlale & scandfale & 1 \\
\hline signaler & signgaler & signcaler & 1 \\
\hline sourdine & sourdnine & sourdcine & 1 \\
\hline
\end{tabular}


(continued)

\begin{tabular}{|c|c|c|c|}
\hline suicider & suicdider & suiclider & 1 \\
\hline trahison & trahsison & trahmison & 1 \\
\hline utiliser & utitliser & utinliser & 1 \\
\hline visiteur & visisteur & visinteur & 1 \\
\hline absenter & absenster & absencter & 2 \\
\hline alentour & alelntour & alepntour & 2 \\
\hline analyser & anaslyser & anamlyser & 2 \\
\hline astiquer & astisquer & astinquer & 2 \\
\hline aviation & aviavtion & aviartion & 2 \\
\hline baptiser & bapstiser & bapltiser & 2 \\
\hline camarade & camadrade & camanrade & 2 \\
\hline cantique & cantinque & cantirque & 2 \\
\hline cartable & carbtable & carstable & 2 \\
\hline champion & chamhpion & chamspion & 2 \\
\hline chantier & chanhtier & chanptier & 2 \\
\hline composer & compomser & compotser & 2 \\
\hline consoler & consonler & consogler & 2 \\
\hline cuisiner & cuisinser & cuisinder & 2 \\
\hline destiner & destisner & destibner & 2 \\
\hline disciple & discisple & discirple & 2 \\
\hline doctrine & doctrcine & doctrline & 2 \\
\hline durement & durenment & duresment & 2 \\
\hline escalier & escalcier & escalpier & 2 \\
\hline euphorie & euphoprie & euphodrie & 2 \\
\hline exigence & exingence & exitgence & 2 \\
\hline extasier & extastier & extaslier & 2 \\
\hline fasciner & fascisner & fascitner & 2 \\
\hline flanquer & flanlquer & flantquer & 2 \\
\hline gaiement & gaienment & gaierment & 2 \\
\hline habitude & habitbude & habitrude & 2 \\
\hline harmonie & harmornie & harmotnie & 2 \\
\hline indiquer & indinquer & indilquer & 2 \\
\hline insolite & insotlite & insorlite & 2 \\
\hline ironique & ironrique & ironsique & 2 \\
\hline magazine & maganzine & magarzine & 2 \\
\hline modestie & modtestie & modrestie & 2 \\
\hline monsieur & monsineur & monsileur & 2 \\
\hline munition & munitnion & munitrion & 2 \\
\hline obstacle & obstlacle & obstracle & 2 \\
\hline pancarte & panctarte & pancharte & 2 \\
\hline patience & paticence & patirence & 2 \\
\hline planquer & planlquer & plansquer & 2 \\
\hline poliment & polinment & polidment & 2 \\
\hline province & pronvince & prolvince & 2 \\
\hline pyramide & pyradmide & pyralmide & 2 \\
\hline religion & religlion & religsion & 2 \\
\hline sagement & sagenment & sagerment & 2 \\
\hline scrupule & scrulpule & scrumpule & 2 \\
\hline solitude & soliltude & solirtude & 2 \\
\hline soulager & souglager & soutlager & 2 \\
\hline syndicat & syndincat & syndircat & 2 \\
\hline triangle & trigangle & trisangle & 2 \\
\hline victoire & victroire & victboire & 2 \\
\hline vocation & vocatcion & vocatrion & 2 \\
\hline adorable & adolrable & adocrable & 3 \\
\hline anecdote & anecdnote & anecdrote & 3 \\
\hline atomique & atomitque & atomilque & 3 \\
\hline auditeur & auditedur & auditelur & 3 \\
\hline basculer & basculser & basculner & 3 \\
\hline boutique & boqutique & bolutique & 3 \\
\hline bricoler & bricorler & bricotler & 3 \\
\hline campagne & camnpagne & camrpagne & 3 \\
\hline cendrier & cendriner & cendriver & 3 \\
\hline chandail & chandhail & chandmail & \\
\hline
\end{tabular}


(continued)

\begin{tabular}{|c|c|c|c|}
\hline chapelet & chapehlet & chaperlet & 3 \\
\hline combiner & combinmer & combinder & 3 \\
\hline comptoir & comptomir & comptolir & 3 \\
\hline consumer & consumner & consumper & 3 \\
\hline devancer & decvancer & delvancer & 3 \\
\hline discuter & discutser & discutler & 3 \\
\hline document & docnument & docrument & 3 \\
\hline employer & employper & employter & 3 \\
\hline encolure & encolnure & encoldure & 3 \\
\hline escargot & escarsgot & escarmgot & 3 \\
\hline examiner & exnaminer & expaminer & 3 \\
\hline fabuleux & fabulebux & fabulemux & 3 \\
\hline fatigant & fatnigant & fatrigant & 3 \\
\hline fixement & fixnement & fixlement & 3 \\
\hline gendarme & gendarnme & gendartme & 3 \\
\hline habituel & habitubel & habiturel & 3 \\
\hline histoire & histoisre & histoinre & 3 \\
\hline insulter & insulnter & insulpter & 3 \\
\hline jalousie & jalouslie & jaloustie & 3 \\
\hline limonade & limdonade & limronade & 3 \\
\hline logement & lognement & logrement & 3 \\
\hline maternel & manternel & masternel & 3 \\
\hline modifier & modifider & modifiler & 3 \\
\hline naviguer & naviguver & naviguler & 3 \\
\hline obstiner & obstibner & obstigner & 3 \\
\hline paniquer & paniquner & paniquher & 3 \\
\hline paquebot & pabquebot & parquebot & 3 \\
\hline plaintif & plainltif & plainstif & 3 \\
\hline pleuvoir & pleuvloir & pleuvboir & 3 \\
\hline ponctuer & ponctuner & ponctuder & 3 \\
\hline prudence & prucdence & prusdence & 3 \\
\hline quatorze & quaztorze & quaptorze & 3 \\
\hline revanche & recvanche & remvanche & 3 \\
\hline sculpter & sculpcter & sculphter & 3 \\
\hline solution & solutilon & solutiron & 3 \\
\hline soulever & sovulever & sobulever & 3 \\
\hline toujours & tourjours & tounjours & 3 \\
\hline tribunal & triburnal & tribusnal & 3 \\
\hline violence & vioclence & viorlence & 3 \\
\hline vraiment & vraniment & vradiment & 3 \\
\hline agricole & agricogle & agricotle & 4 \\
\hline ambiance & amcbiance & amtbiance & 4 \\
\hline apitoyer & apitoyper & apitoyder & 4 \\
\hline argument & arngument & arpgument & 4 \\
\hline aveugler & alveugler & adveugler & 4 \\
\hline balancer & bcalancer & bhalancer & 4 \\
\hline bestiole & bestiolse & bestiolde & 4 \\
\hline bracelet & bracelret & bracelnet & 4 \\
\hline caniveau & caniveanu & canivealu & 4 \\
\hline caravane & canravane & catravane & 4 \\
\hline chantage & chantahge & chantarge & 4 \\
\hline charogne & chnarogne & chbarogne & 4 \\
\hline conduire & cornduire & cojnduire & 4 \\
\hline craintif & craintrif & craintlif & 4 \\
\hline croisade & croisarde & croisande & 4 \\
\hline dimanche & dihmanche & dirmanche & 4 \\
\hline disputer & ditsputer & dinsputer & 4 \\
\hline domicile & dolmicile & dotmicile & 4 \\
\hline enfilade & enfilande & enfilarde & 4 \\
\hline enjamber & enjambner & enjambler & 4 \\
\hline esquiver & evsquiver & elsquiver & 4 \\
\hline exclamer & exclamxer & exclamter & 4 \\
\hline fatiguer & fatiguetr & fatiguenr & 4 \\
\hline flagrant & flagralnt & flagrasnt & 4 \\
\hline
\end{tabular}


(continued)

\begin{tabular}{|c|c|c|c|}
\hline fraction & fractiron & fractibon & 4 \\
\hline glorieux & glorielux & gloriedux & 4 \\
\hline habituer & habituebr & habituenr & 4 \\
\hline investir & investnir & investlir & 4 \\
\hline jardinet & jardinert & jardinept & 4 \\
\hline jugement & jungement & jucgement & 4 \\
\hline longueur & longueunr & longueutr & 4 \\
\hline machinal & mnachinal & msachinal & 4 \\
\hline milicien & milicieln & miliciern & 4 \\
\hline moquerie & mroquerie & mnoquerie & 4 \\
\hline narquois & narquoirs & narquoips & 4 \\
\hline objecter & objectber & objectler & 4 \\
\hline originel & originrel & origindel & 4 \\
\hline paradoxe & paxradoxe & pamradoxe & 4 \\
\hline peinture & perinture & pedinture & 4 \\
\hline poignard & porignard & pofignard & 4 \\
\hline position & positiosn & positiorn & 4 \\
\hline rigolade & ridgolade & ringolade & 4 \\
\hline salement & sanlement & sadlement & 4 \\
\hline sanglier & sanglienr & sanglietr & 4 \\
\hline somnoler & slomnoler & stomnoler & 4 \\
\hline soutenir & snoutenir & scoutenir & 4 \\
\hline tourment & tonurment & tolurment & 4 \\
\hline tropical & tropicral & tropicmal & 4 \\
\hline troupeau & trouperau & troupebau & 4 \\
\hline virginie & virginire & virginide & 4 \\
\hline
\end{tabular}

Open Access This article is licensed under a Creative Commons Attribution 4.0 International License, which permits use, sharing, adaptation, distribution and reproduction in any medium or format, as long as you give appropriate credit to the original author(s) and the source, provide a link to the Creative Commons licence, and indicate if changes were made. The images or other third party material in this article are included in the article's Creative Commons licence, unless indicated otherwise in a credit line to the material. If material is not included in the article's Creative Commons licence and your intended use is not permitted by statutory regulation or exceeds the permitted use, you will need to obtain permission directly from the copyright holder. To view a copy of this licence, visit http://creativecommons.org/licenses/by/4.0/.

\section{References}

Adelman, J. S., Marquis, S. J., \& Sabatos-DeVito, M. G. (2010). Letters in words are read simultaneously, not in left-to-right sequence. Psychological Science, 21, 1799-1801.

Andrews, S. (1996). Lexical retrieval and selection processes: Effects of transposed-letter confusability. Journal of Memory and Language, 35, 775-800.

Baayen, R. (2008). Analyzing Linguistic Data: A Practical Introduction to Statistics Using R. Cambridge: Cambridge University Press.

Baayen, R., Davidson, D., \& Bates, D. (2008). Mixed-effects modeling with crossed random effects for subjects and items. Journal of Memory and Language. 59, 390-412.

Balota, D. A., Yap, M. J., Hutchison, K. A., Cortese, M. J., Kessler, B., Loftis, B., ... Treiman, R. (2007). The English Lexicon Project. Behavior Research Methods, 39, 445-459.
Barr, D. J., Levy, R., Scheepers, C., \& Tily, H. J. (2013). Random effects structure for confirmatory hypothesis testing: Keep it maximal. Journal of Memory and Language, 68.

Bates, D., Mächler, M., Bolker, B., \& Walker, S. (2015). Fitting linear mixed-effects models using lme4. Journal of Statistical Software, 67, 1-48.

Bjork, E. L. \& Murray, J. T. (1977). On the nature of input channels in visual processing. Psychological Review, 84, 472-484.

Bruner, J. S. \& O'Dowd, D. (1958). A note on the informativeness of parts of words. Language and Speech, 1, 98-101.

Brysbaert, M., Stevens, M., Mandera, P., \& Keuleers, E. (2016). The impact of word prevalence on lexical decision times: evidence from the Dutch Lexicon Project 2. Journal of Experimental Psychology: Human Perception and Performance, 42, 441-458.

Caramazza, A., \& Miceli, G. (1990). The structure of graphemic representations. Cognition, 27, 243-297.

Chambers, S. M. (1979). Letter and order information in lexical access. Journal of Verbal Learning and Verbal Behavior, 18, 225-241.

Davis, C. J. (2010). The spatial coding model of visual word identification. Psychological Review. 117, 713-58.

Davis, C. J., Perea, M., \& Acha, J. (2009). Re(de)fining the orthographic neighborhood: The role of addition and deletion neighbors in lexical decision and reading. Journal of Experimental Psychology: Human Perception and Performance, 35, 1550-1570.

Duñabeitia, J.A., Dimitropoulou, M., Grainger, J., Hernández, J.A., \& Carreiras, M. (2012). Differential sensitivity of letters, numbers and symbols to character transpositions. Journal of Cognitive Neuroscience, 24, 1610-1624.

Ferrand, L., New, B., Brysbaert, M., Keuleers, E., Bonin, P., Méot, A., ... Pallier, C. (2010). The French Lexicon Project: Lexical decision data for 38,840 French words and 38,840 pseudowords. Behavior Research Methods, 42, 488-496.

Fischer-Baum, S. (2017). The independence of letter identity and letter doubling in reading. Psychonic Bulletin \& Review, 24, 873-878. 
Frankish, C. \& Turner E. (2007). SIHGT and SUNOD: The role of orthography and phonology in the perception of transposed letter anagrams. Journal of Memory and Language, 56, 189-211.

Gomez, P. (2020). Overlap Model Code. Retrieved from psyarxiv.com/ 67g2f. https://doi.org/10.31234/osf.io/67g2f

Gomez, P., Ratcliff, R., \& Perea, M. (2008). The overlap model: A model of letter position coding. Psychological Review, 115, 577-600.

Grainger, J. (2018). Orthographic processing: A 'mid-level' vision of reading: The 44th Sir Frederic Bartlett Lecture. The Quarterly Journal of Experimental Psychology, 71, 335-359.

Grainger, J. \& Hannagan, T. (2014). What is special about orthographic processing? Written Language \& Literacy, 17, 225-252.

Grainger, J. \& van Heuven, W. J. B. (2004). Modeling letter position coding in printed word perception. In P. Bonin (Ed.), Mental Lexicon. New York: Nova Science Publishers.

Grainger, J. \& Whitney, C. (2004). Does the huamn mind raed wrods as a wlohe? Trends in Cognitive Sciences, 8, 58-59.

Grainger, J. \& Ziegler, J.C. (2011). A dual-route approach to orthographic processing. Frontiers in Psychology, 2:54. https://doi.org/10.3389/ fpsyg.2011.00054.

Green, P. \& MacLeod, C. (2016). SIMR: An R package for power analysis of generalized linear mixed models by simulation. Methods in Ecology and Evolution, 7, 493-498.

Hannagan, T. \& Grainger, J. (2012). Protein analysis meets visual word recognition: A case for String kernels in the brain. Cognitive Science, 36, 575-606.

Harris, C.L. \& Morris, A.L. (2000). Orthographic repetition blindness. The Quarterly Journal of Experimental Psychology, 53, 1039-60.

Kanwisher, N. (1991). Repetition blindness and illusory conjunctions: Errors in binding visual types with visual tokens. Journal of Experimental Psychology: Human Perception and Performance, 17, 404-421.

Keuleers, E., Lacey, P., Rastle, K., \& Brysbaert, M. (2012). The British Lexicon Project: Lexical decision data for 28,730 monosyllabic and disyllabic English words. Behavior Research Methods, 44, 287-304.

Luo, C. R. \& Caramazza, A. (1996). Temporal and spatial repetition blindness: Effects of presentation mode and repetition lag on the perception of repeated items. Journal of Experimental Psychology: Human Perception and Performance, 22, 95-113.

Massol, S., Duñabetia, J.A., Carreiras, M., \& Grainger, J. (2013). Evidence for letter-specific position coding mechanisms. PLoS ONE, 8(7), e68460. https://doi.org/10.1371/journal.pone.0068460
Mathôt, S., Schreij, D., \& Theeuwes, J. (2012). OpenSesame: An opensource, graphical experiment builder for the social sciencses. Behavior Research Methods, 44, 314-324.

Meade, G., Mahnich, C., Holcomb, P.J., \& Grainger, J. (2020). Orthographic neighborhood density modulates the size of transposed-letter priming effects. Manuscript submitted for publication.

Mozer, M.C. (1989). Types and tokens in visual letter perception. Journal of Experimental Psychology: Human Perception and Performance, $15,287-303$

New, B. \& Grainger, J. (2011). On letter frequency effects. Acta Psychologica, 138, 322-328.

New, B., Pallier, C., Brysbaert, M., Ferrand, L. (2004). Lexique 2: A New French Lexical Database. Behavior Research Methods, Instruments, \& Computers, 36, 516-524.

O'Connor, R.E. \& Forster, K.I. (1981). Criterion bias and search sequence bias in word recognition. Memory \& Cognition 9, 78-92.

Perea, M., Rosa, E. \& Gómez, C. (2005). The frequency effect for pseudowords in the lexical decision task. Perception \& Psychophysics, 67, 301-314.

R Core Team. (2017). R: A Language and Environment for Statistical Computing. Retrieved from http://www.R-project.org/

Schoonbaert, S. \& Grainger, J. (2004). Letter position coding in printed word perception: Effects of repeated and transposed letters. Language and Cognitive Processes, 19, 333-367.

Snell, J., van Leipsig, S., Grainger, J. \& Meeter, M. (2018). OB1-reader: A model of word recognition and eye movements in text reading. Psychological Review, 125, 969-984.

Trifonova, I.V. \& Adelman, J.S. (2019). A delay in processing for repeated letters: Evidence from megastudies. Cognition, 189, 227-241.

van Heuven, W. J., Mandera, P., Keuleers, E., \& Brysbaert, M. (2014). SUBTLEX-UK: A new and improved word frequency database for British English. The Quarterly Journal of Experimental Psychology, 67, 1176-1190.

Whitney, C. (2001). How the brain encodes the order of letters in a printed word: The SERIOL model and selective literature review. Psychonomic Bulletin \& Review 8, 221-243.

Yarkoni, T., Balota, D., \& Yap, M. (2008). Moving beyond Coltheart's $\mathrm{N}$ : A new measure of orthographic similarity. Psychonomic Bulletin \& Review, 15, 971-979.

Publisher's note Springer Nature remains neutral with regard to jurisdictional claims in published maps and institutional affiliations. 